Research Article

\title{
Glyphosate-Resistant Canada Fleabane Control in Winter Wheat with Postemergence Herbicides
}

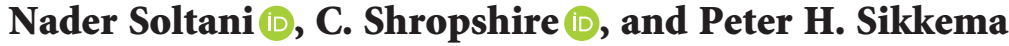 \\ University of Guelph Ridgetown Campus, Ridgetown ON NOP 2CO, Canada \\ Correspondence should be addressed to Nader Soltani; soltanin@uoguelph.ca
}

Received 8 April 2020; Revised 16 June 2020; Accepted 2 July 2020; Published 30 July 2020

Academic Editor: Allen Barker

Copyright (C) 2020 Nader Soltani et al. This is an open access article distributed under the Creative Commons Attribution License, which permits unrestricted use, distribution, and reproduction in any medium, provided the original work is properly cited.

\begin{abstract}
In recent years, there has been a rapid increase in the number of herbicide-resistant weeds, including glyphosate-resistant (GR) biotypes in Ontario, Canada. A total of six field experiments were conducted over a two-year period (2018 and 2019 ) to determine the control of GR Canada fleabane (Conyza canadensis (L.) Cronq.) with currently available herbicides for winter wheat in Ontario. Winter wheat was not injured with any of the herbicides evaluated. Among herbicides evaluated, pyrasulfotole/bromoxynil (preformulated), 2,4-D ester, halauxifen, fluroxypyr/halauxifen (preformulated) + MCPA, pyrasulfotole/bromoxynil/fluroxypyr (preformulated), pyrasulfotole/bromoxynil/thiencarbazone (preformulated), pyrasulfotole/ bromoxynil/thiencarbazone + MCPA, and fluroxypyr/halauxifen + pyroxsulam + MCPA controlled GR Canada fleabane $94-100 \%$ at 8 weeks after application (WAA) and reduced density $95-100 \%$ and biomass $97-100 \%$. Reduced GR Canada fleabane interference with pyrasulfotole/bromoxynil/thiencarbazone + MCPA increased winter wheat yield 27\% compared to the weedy control. GR Canada fleabane interference had no adverse effect on winter wheat yield with all other treatments. Based on these results, herbicide treatments that include 2,4-D, pyrasulfotole, or halauxifen can adequately control GR Canada fleabane in winter wheat.
\end{abstract}

\section{Introduction}

Winter wheat (Triticum aestivum L.) is a cereal crop in Ontario that growers often rotate with their soybean and corn crops. In 2019 in Ontario, over 2 million tonnes of winter wheat was harvested from 400 thousand hectares with a market value of approximately $\$ 500$ million [1]

In recent years, there has been an expeditious rise in the number of herbicide-resistant weeds, including glyphosateresistant (GR) biotypes, because of large-scale glyphosate use in glyphosate-resistant crops, the increased use of notill practices and therefore the increased use of glyphosate as a burndown, reduced use of herbicides with an alternate mode-of-action, and greater movement of farm machinery and produce $[2,3]$. There has been movement of these herbicide-resistant weed biotypes from farm to farm, township to township, and county to county across Ontario. Glyphosate-resistant Canada fleabane (Conyza canadensis (L.) Cronq.) was initially confirmed in 2010 in one county (Essex) in Ontario [4]. It has spread rapidly to 30 counties across the province [5]. The challenge of managing herbicide-resistant weed biotypes has been exacerbated in recent years with the advent of multiple-resistant biotypes. Today, there is Group 2 and 9 resistant Canada fleabane in Ontario.

Winter wheat is sensitive to weed interference. In a metaanalysis from trials conducted across North America, Flessner et al. [6] reported an average of $22 \%$ winter wheat yield loss when Best Management Practices (BMP) were used and weeds were left uncontrolled. Weeds such as GR Canada fleabane competes with winter wheat for light, water, space, and nutrients and can cause significant yield losses in winter wheat [7]. Quinn et al. [8] found a 13\% numeric yield decrease due to GR Canada fleabane interference in winter wheat.

The discovery of GR weeds in Ontario has provided a market opportunity for various agri-chemical companies that have herbicides with activity on these GR biotypes as 
they may provide an efficacious, cost-effective weed management solution for the control of these yield robbing weed biotypes. Currently, the herbicide that is used most frequently for GR Canada fleabane control in winter wheat is pyrasulfotole/bromoxynil (preformulated). The overreliance on one herbicide can increase selection pressure for herbicide-resistant genotypes. Additional weed control options are necessary for long-term, sustainable crop production programs.

The aim of this study was to assess pyrasulfotole/bromoxynil, 2,4-D ester, thifensulfuron-ethyl/tribenuronmethyl (preformulated) + fluroxypyr + MCPA ester, halauxifenmethyl, fluroxypyr/halauxifen-methyl (preformulated) + MCPA EHE, pyroxsulam, pyrasulfotole/bromoxynil/fluroxypyr (preformulated), pyrasulfotole/bromoxynil/thiencarbazone-methyl (preformulated), pyrasulfotole/bromoxynil/thiencarbazone-methyl + MCPA ester, tribenuron-methyl+ thiencarbazone-methyl, tribenuron-methyl + thiencarbazonemethyl + MCPA ester, fluroxypyr/bromoxynil/MCPA (preformulated), tolpyralate, and fluroxypyr/halauxifenmethyl + pyroxsulam + MCPA for the control GR Canada fleabane in winter wheat. To our knowledge, no study has compared the efficacy of these herbicide options for the control of GR Canada fleabane in winter wheat in Ontario. Using ineffective herbicide options can decrease winter wheat yield, reduce net profit, and result in a needless application of pesticides into the environment. Additionally, it is critical for cereal producers to know which herbicide/herbicide tank-mixtures provide the most efficacious GR Canada fleabane control in winter wheat. As a result, only effective herbicides will be applied which in turn will minimize the environmental loading of pesticides, improve weed control efficacy, and increase net returns to producers.

\section{Materials and Methods}

A total of six experiments were conducted over a two-year period $(2018,2019)$ in winter wheat fields infested with GR Canada fleabane. Field trials were located near Ridgetown (42.458138, -81.882041), Blenheim (42.330170, -82.029603), and Ridgetown (42.504121, -81.915343) in 2018 and near Ridgetown (42.460798, -81.884509), Botany (42.486860, -81.992258) and Morpeth $(42.413690,-81.800850)$ in 2019.

Experiments were arranged in a randomized complete block design with four replications. There were 16 treatments consisting of weed-free control, weedy control, pyrasulfotole/ bromoxynil $\left(205 \mathrm{~g}_{\text {ai ha }}{ }^{-1}\right), 2,4-\mathrm{D}$ ester $\left(850 \mathrm{~g}\right.$ ai ha $\left.{ }^{-1}\right)$, thifensulfuron-ethyl/tribenuron-methyl + fluroxypyr + MCPA

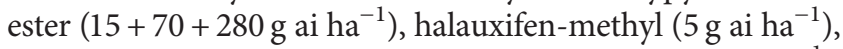
fluroxypyr/halauxifen-methyl + MCPA EHE $\left(82+372 \mathrm{~g} \mathrm{ai} \mathrm{ha}^{-1}\right)$, pyroxsulam ( $15 \mathrm{~g}$ ai $\mathrm{ha}^{-1}$ ), pyrasulfotole/bromoxynil/ fluroxypyr (277g ai ha ${ }^{-1}$ ), pyrasulfotole/bromoxynil/thiencarbazone-methyl (211 $\mathrm{g}$ ai ha $\left.^{-1}\right)$, pyrasulfotole/bromoxynil/ thiencarbazone-methyl + MCPA ester $\left(211+280 \mathrm{~g}_{\text {ai ha }}{ }^{-1}\right)$, tribenuron-methyl + thiencarbazone-methyl $\left(7.5+5 \mathrm{~g} \mathrm{ai} \mathrm{ha}^{-1}\right)$, tribenuron-methyl + thiencarbazone-methyl + MCPA ester $\left(7.5+5+280 \mathrm{~g}\right.$ ai $\left.\mathrm{ha}^{-1}\right)$, fluroxypyr/bromoxynil/MCPA $\left(600 \mathrm{~g}\right.$ ai ha $\left.{ }^{-1}\right)$, tolpyralate $\left(40 \mathrm{~g}\right.$ ai ha $\left.{ }^{-1}\right)$, and fluroxypyr/ halauxifen-methyl + pyroxsulam + MCPA EHE $(82+15+372 \mathrm{~g}$ ai $\mathrm{ha}^{-1}$ ). Adjuvants used were based on the herbicide manufacturers' recommendations and are listed in Table 1.

Plots were $2 \mathrm{~m}$ wide by $8 \mathrm{~m}$ long. Winter wheat ' $25 \mathrm{R} 40$ ' (DuPont Pioneer, Mississauga, ON) was seeded with a double-disc drill at $140-150 \mathrm{~kg} \mathrm{ha}^{-1}$ in rows spaced $19 \mathrm{~cm}$ apart at a depth of $3 \mathrm{~cm}$ in early October of 2017 and 2018. Plots were not irrigated throughout the growing season.

Herbicides were applied (when GR Canada fleabane was less than $10 \mathrm{~cm}$ in height) with a $\mathrm{CO}_{2}$-pressurized backpack sprayer calibrated to deliver $200 \mathrm{~L}$ of spray solution $\mathrm{ha}^{-1}$. The sprayer was equipped with a $1.5 \mathrm{~m}$ wide handheld boom with four ULD nozzles (Hypro, New Brighton, MN) which produced a $2.0 \mathrm{~m}$ spray width.

Visible winter wheat injury was evaluated 1,2 , and 4 weeks after applicaiton (WAA) and GR Canada fleabane control was evaluated at 2,4 , and 8 WAA on a scale of 0 to $100 \%(0=$ no visible injury/no control and $100=$ plant death/total control). Density was determined at 4 WAA by counting the number of GR Canada fleabane plants within two $0.25 \mathrm{~m}^{2}$ quadrats randomly placed in each plot. Biomass was then determined by harvesting the aboveground section of GR Canada fleabane plants within each quadrat and drying them in a paper bag at $60^{\circ} \mathrm{C}$ for a minimum of 48 hours. At maturity, a small plot combine was used to harvest winter wheat, and grain moisture content and weight were recorded. Yield data were adjusted to $14 \%$ moisture content.

The GLIMMIX procedure in SAS [9] was utilized for data analysis. The fixed effect consisted of herbicide treatment, and random effects were environment (yearlocation combinations), treatment by environment interaction, and replicate within environment. The assumptions for analysis and distributions within GLIMMIX were checked by plotting studentized residuals against predicted, environment, treatment, and replicate for each variable, as well as using the Shapiro-Wilk statistic [9]. To meet normality assumptions, visual estimates of GR Canada fleabane control 4 and 8 WAA were arcsine square-root transformed prior to analysis, while control 2 WAA and wheat yield needed no transformation. The lognormal distribution was utilized for GR Canada fleabane density and dry biomass. Means for all variables were separated at $P \leq 0.05$ on the model scale using Tukey's HSD. Any treatments with assigned values, and therefore having no variance, were excluded from the analysis. However, in the case of GR Canada fleabane control for the weedy control and density and dry biomass for the weedfree control, all assigned to be 0 , comparisons with the value zero were still possible using the $P$-value from the LSMEAN output.

\section{Results and Discussion}

At 1,2, and 4 WAA, there was no visible winter wheat injury from any of the herbicides evaluated. Previous research has similarly shown no significant visible injury with herbicides such as 2,4-D, pyrasulfotole, bromoxynil, thifensulfuron, tribenuron, prosulfuron, fluroxypyr, or MCPA mixtures at comparable rates in winter wheat [10-12]. However, 
TABLE 1: Glyphosate-resistant Canada fleabane (GRCF) control 2, 4, and 8 weeks after herbicide application (WAA), GRCF density, and dry biomass 4 WAA and winter wheat yield for herbicides applied postemergence from 6 sites in southwestern Ontario in 2018-2019.

\begin{tabular}{|c|c|c|c|c|c|c|c|}
\hline \multirow[b]{2}{*}{ Herbicide treatment } & \multirow{2}{*}{$\begin{array}{l}\text { Rate } \\
\left(\mathrm{g} \mathrm{ai} \mathrm{ha}^{-1}\right)\end{array}$} & \multicolumn{3}{|c|}{ GRCF Control (\%) } & \multirow{2}{*}{$\begin{array}{l}\text { GRCF density } \\
\text { (plants } \mathrm{m}^{-2} \text { ) }\end{array}$} & \multirow{2}{*}{$\begin{array}{l}\text { GRCF dry } \\
\text { biomass } \\
\left(\mathrm{g} \mathrm{m}^{-2}\right)\end{array}$} & \multirow{2}{*}{$\begin{array}{l}\text { Winter wheat } \\
\text { yield }\left(\mathrm{T} \mathrm{ha}^{-1}\right)\end{array}$} \\
\hline & & $\begin{array}{c}2 \\
\text { WAA }\end{array}$ & $\begin{array}{c}4 \\
\text { WAA }\end{array}$ & $\begin{array}{c}8 \\
\text { WAA }\end{array}$ & & & \\
\hline Weed-free control & & 100 & 100 & 100 & $0 \mathrm{a}$ & $0 \mathrm{a}$ & $4.13 \mathrm{ab}$ \\
\hline Weedy control & & $0 \mathrm{f}$ & $0 \mathrm{e}$ & $0 \mathrm{e}$ & $142.1 \mathrm{~h}$ & $10.8 \mathrm{e}$ & $3.58 \mathrm{~b}$ \\
\hline Pyrasulfotole/bromoxynil + AMSa $\left(1 \mathrm{~L} \mathrm{ha}^{-1}\right)$ & 205 & $89 \mathrm{ab}$ & $97 \mathrm{ab}$ & $98 \mathrm{ab}$ & $0.7 \mathrm{abc}$ & $0.25 \mathrm{abc}$ & $4.31 \mathrm{ab}$ \\
\hline $2,4-\mathrm{D}$ ester & 850 & $76 \mathrm{abc}$ & $93 \mathrm{ab}$ & $94 \mathrm{ab}$ & 6.4 bcde & $0.37 \mathrm{abc}$ & $4.09 \mathrm{ab}$ \\
\hline $\begin{array}{l}\text { Thifensulfuron-ethyl/tribenuron- } \\
\text { methyl + fluroxypyr + MCPA ester + NISb } \\
(0.2 \% \mathrm{v} / \mathrm{v})\end{array}$ & $15+70+280$ & $62 \mathrm{bcd}$ & $74 \mathrm{bc}$ & $71 \mathrm{bc}$ & $17.1 \mathrm{def}$ & $1.46 \mathrm{bc}$ & $3.96 \mathrm{ab}$ \\
\hline Halauxifen-methyl + MSOc (1\% v/v) & 5 & $76 \mathrm{abc}$ & $98 \mathrm{ab}$ & $99 \mathrm{ab}$ & $0.8 \mathrm{abc}$ & $0.08 \mathrm{ab}$ & $4.36 \mathrm{ab}$ \\
\hline Fluroxypyr/halauxifen-methyl + MCPA EHE & $82+372$ & $78 \mathrm{abc}$ & $97 \mathrm{ab}$ & $98 \mathrm{ab}$ & $1.9 \mathrm{abcd}$ & $0.20 \mathrm{abc}$ & $4.19 \mathrm{ab}$ \\
\hline Pyroxsulam + NIS $(0.25 \%$ v/v $)+$ UANd $\left(2 \mathrm{~L} \mathrm{ha}^{-1}\right)$ & 15 & $19 \mathrm{e}$ & $8 \mathrm{~d}$ & $7 \mathrm{~d}$ & $49.9 \mathrm{fg}$ & $8.58 \mathrm{de}$ & $3.96 \mathrm{ab}$ \\
\hline Pyrasulfotole/bromoxynil/fluroxypyr & 277 & $91 \mathrm{ab}$ & $98 \mathrm{ab}$ & $98 \mathrm{ab}$ & $2.3 \mathrm{abcd}$ & $0.20 \mathrm{abc}$ & $4.16 \mathrm{ab}$ \\
\hline $\begin{array}{l}\text { Pyrasulfotole/bromoxynil/thiencarbazone- } \\
\text { methyl + AMS (1 L ha-1) }\end{array}$ & 211 & $94 \mathrm{a}$ & $100 \mathrm{a}$ & $100 \mathrm{a}$ & $0.1 \mathrm{ab}$ & $0.02 \mathrm{ab}$ & $4.56 \mathrm{a}$ \\
\hline $\begin{array}{l}\text { Pyrasulfotole/bromoxynil/thiencarbazone- } \\
\left.\text { methyl + MCPA ester + AMS (1 L ha }{ }^{-1}\right)\end{array}$ & $211+280$ & $95 \mathrm{a}$ & $100 \mathrm{a}$ & $100 \mathrm{a}$ & $0.8 \mathrm{abc}$ & $0.02 \mathrm{ab}$ & $4.15 \mathrm{ab}$ \\
\hline $\begin{array}{l}\text { Tribenuron-methyl + thiencarbazone-methyl + } \\
\text { AMS (1 L ha-1) }\end{array}$ & $7.5+5$ & $11 \mathrm{ef}$ & $5 \mathrm{de}$ & $4 \mathrm{de}$ & $55.1 \mathrm{gh}$ & $7.17 \mathrm{de}$ & $4.02 \mathrm{ab}$ \\
\hline $\begin{array}{l}\text { Tribenuron-methyl + thiencarbazone-methyl + } \\
\text { MCPA ester + AMS }\left(1 \mathrm{~L} \mathrm{ha}^{-1}\right)\end{array}$ & $7.5+5+280$ & 38 de & $38 \mathrm{~cd}$ & $33 \mathrm{~cd}$ & $28.4 \mathrm{efg}$ & $3.12 \mathrm{~cd}$ & $3.93 \mathrm{ab}$ \\
\hline Fluroxypyr/bromoxynil/MCPA & 600 & $\begin{array}{c}67 \\
\mathrm{abcd}\end{array}$ & $81 \mathrm{abc}$ & $84 \mathrm{ab}$ & $13.7 \mathrm{cdef}$ & $0.94 \mathrm{bc}$ & $3.67 \mathrm{ab}$ \\
\hline Tolpyralate + MSO $(0.5 \% \mathrm{v} / \mathrm{v})+$ UAN $(2.5 \% \mathrm{v} / \mathrm{v})$ & 40 & $57 \mathrm{~cd}$ & $73 \mathrm{bc}$ & $78 \mathrm{ab}$ & 6.9 bcdef & $0.52 \mathrm{abc}$ & $4.22 \mathrm{ab}$ \\
\hline $\begin{array}{l}\text { Fluroxypyr/halauxifen-methyl + pyroxsulam + } \\
\text { MCPA EHE + NIS }(0.25 \% \text { v/v })\end{array}$ & $82+15+372$ & $79 \mathrm{ab}$ & $96 \mathrm{ab}$ & $96 \mathrm{ab}$ & $1.8 \mathrm{abcd}$ & $0.23 \mathrm{abc}$ & $3.92 \mathrm{ab}$ \\
\hline
\end{tabular}

Means within a column followed by the same lowercase letter do not differ significantly according to Tukey's HSD at $P \leq 0.05$ Ammonium sulfate. ${ }^{b}$ Nonionic surfactant. ${ }^{\mathrm{c}}$ Methylated seed oil. ${ }^{\mathrm{d}} 28 \%$ urea ammonium nitrate.

Reddy et al. [13] observed as much as $4 \%$ winter wheat injury with pyrasulfotole applied alone or in combination with metsulfuron, bromoxynil, dicamba, or MCPA.

At 2 WAA, pyrasulfotole/bromoxynil, 2,4-D ester, halauxifen, fluroxypyr/halauxifen + MCPA, pyrasulfotole/bromoxynil/ fluroxypyr, pyrasulfotole/bromoxynil/thiencarbazone, pyrasulfotole/bromoxynil/thiencarbazone + MCPA, and fluroxypyr/ halauxifen + pyroxsulam + MCPA controlled GR Canada fleabane 76-95\%. Thifensulfuron/tribenuron + fluroxypyr + MCPA, fluroxypyr/bromoxynil/MCPA, and tolpyralate provided 57-67\% control, and pyroxsulam, tribenuron + thiencarbazone, and tribenuron + thiencarbazone + MCPA provided only 11-38\% control (Table 1).

GR Canada fleabane control generally increased over time. At 4 WAA, pyrasulfotole/bromoxynil, 2,4-D ester, halauxifen, fluroxypyr/halauxifen + MCPA, pyrasulfotole/bromoxynil/fluroxypyr, pyrasulfotole/bromoxynil/thiencarbazone, pyrasulfotole/ bromoxynil/thiencarbazone + MCPA, and fluroxypyr/halauxifen + pyroxsulam + MCPA controlled GR Canada fleabane $93-100 \%$. Thifensulfuron/tribenuron + fluroxypyr + MCPA, fluroxypyr/ bromoxynil/MCPA, and tolpyralate provided $73-81 \%$ control, and pyroxsulam, tribenuron + thiencarbazone, and tribenuron + thiencarbazone + MCPA provided minimal control (5-38\%) of GR Canada fleabane in winter wheat (Table 1).
GR Canada fleabane control was generally the highest at 8 WAA which can be attributed to the competitiveness of a vigorous winter wheat crop. Pyrasulfotole/bromoxynil, 2,4-D ester, halauxifen, fluroxypyr/halauxifen + MCPA, pyrasulfotole/ bromoxynil/fluroxypyr, pyrasulfotole/bromoxynil/thiencarbazone, pyrasulfotole/bromoxynil/thiencarbazone + MCPA, and fluroxypyr/halauxifen + pyroxsulam + MCPA provided excellent control (94-100\%) of GR Canada fleabane in winter wheat. However, thifensulfuron/tribenuron + fluroxypyr + MCPA, fluroxypyr/bromoxynil/MCPA, and tolpyralate provided fair control (71-84\%) of GR Canada fleabane at 8 WAA in winter wheat (Table 1).Other herbicides evaluated including pyroxsulam, tribenuron + thiencarbazone, and tribenuron + thiencarbazone + MCPA provided poor control (4-33\%) of GR Canada fleabane at 8 WAA in winter wheat (Table 1). Results are similar to Mahoney et al. [12] who found $89,67,91,83,96,60,74,87,97$, and $56 \%$ control of GR Canada fleabane with 2,4-D, MCPA, dicamba/ MCPA/mecoprop, dichlorprop/2,4-D, clopyralid, bromoxynil/ $\mathrm{MCPA}$, thifensulfuron/tribenuron + MCPA, fluroxypyr + MCPA, pyrasulfotole/bromoxynil, and prosulfuron + bromoxynil at 8 WAA, respectively. Other studies have found $90-100 \%$ control of GR Canada fleabane with 2,4-D and dichlorprop/2,4-D [14-16]. Kumar et al. [17] also reported 97, 82-94, 85-100, 91-97, 83-85, and $85-92 \%$ control of GR Canada fleabane with pyrasulfotole/ 
bromoxynil, 2,4-D, bromoxynil + fluroxypyr, bromoxynil/MCPA, fluroxypyr, and halauxifen + florasulam, respectively. In another study, GR Canada fleabane was controlled 90\% with halauxifen and $71 \%$ with $2,4-\mathrm{D}$ in soybean $[18,19]$. However, McCauley et al. [20] reported only $65-80 \%$ control of GR Canada fleabane with halauxifen in noncropped fields.

Herbicide treatments that were rated the highest for visible GR Canada fleabane control also caused the greatest GR Canada fleabane density and biomass reduction in winter wheat (Table 1). Pyrasulfotole/bromoxynil, 2,4-D ester, halauxifen, fluroxypyr/halauxifen + MCPA, pyrasulfotole/bromoxynil/fluroxypyr, pyrasulfotole/bromoxynil/thiencarbazone, pyrasulfotole/bromoxynil/thiencarbazone + MCPA, and fluroxypyr/halauxifen + pyroxsulam $+\mathrm{MCPA}$ reduced GR Canada fleabane density $95-100 \%$ and biomass $97-100 \%$ in winter wheat. Thifensulfuron/tribenuron + fluroxypyr + MCPA, fluroxypyr/bromoxynil/MCPA, and tolpyralate reduced GR Canada fleabane density $88-95 \%$ and biomass $86-95 \%$. Pyroxsulam, tribenuron + thiencarbazone, and tribenuron + thiencarbazone + MCPA reduced GR Canada fleabane density $61-80 \%$ and biomass $21-71 \%$ (Table 1 ).

Similar to the findings in this study, Mahoney et al. [12] reported 98, 87, 94, 77, 92, 94, and 99\% density reduction and $97,90,96,88,96,96$, and $100 \%$ biomass reduction in GR Canada fleabane with 2,4-D, MCPA, dichlorprop/2,4-D, bromoxynil/MCPA, thifensulfuron/tribenuron + MCPA, fluroxypyr + MCPA, and pyrasulfotole/bromoxynil in winter wheat, respectively. Kumar et al. [17] also reported 89-90, 78-87, 80-87, 78-87, 88-90, and 78-86\% reduction in shoot biomass of GR Canada fleabane with pyrasulfotole/bromoxynil, 2,4-D, bromoxynil + fluroxypyr, bromoxynil/MCPA, fluroxypyr, and halauxifen + florasulam, respectively. In another study, GR Canada fleabane density was reduced $75 \%$ with halauxifen and $60 \%$ with $2,4-\mathrm{D}[18,19]$.

Winter wheat yield was comparable for all herbicides evaluated. Reduced GR Canada fleabane interference with pyrasulfotole/bromoxynil/thiencarbazone + MCPA resulted in a winter yield increase of $27 \%$ relative to the weedy control. Reduced GR Canada fleabane interference with all of the herbicide treatments evaluated resulted in winter wheat yield that was similar to the weed-free control (Table 1).

\section{Conclusions}

Based on these results, all herbicide treatments that included 2,4-D, pyrasulfotole or halauxifen provide excellent control of GR Canada fleabane in winter wheat. Additionally, there is potential for the control of GR Canada fleabane with thifensulfuron/tribenuron + fluroxypyr + MCPA, fluroxypyr/ bromoxynil/MCPA, and tolpyralate in winter wheat. However, pyroxsulam, tribenuron + thiencarbazone and tribenuron + thiencarbazone + MCPA do not provide adequate control of GR Canada fleabane in winter wheat.

\section{Data Availability}

The data used to support the findings are presented in the manuscript.

\section{Conflicts of Interest}

The authors declare that there are no conflicts of interest regarding the publication of this paper.

\section{Acknowledgments}

This study was financially supported by Grain Farmers of Ontario.

\section{References}

[1] Ontario Ministry of Agriculture, Food and Rural Affairs [OMAFRA] . Area, Yield, Production and Farm Value of Specified Field Crops (Imperial and Metric Units), Ontario of Agriculture, Food and Rural Affairs, Guelph, Ontario, Canada, 2019, http://www.omafra.gov.on.ca/english/stats/crops/ index.html.

[2] B. Klein, Weed Management in Winter Wheat, University of Nebraska-Lincoln Institute of Agriculture and Natural Resources, Lincoln, NE, USA, 2019, https://cropwatch.unl.edu/ weed-management-winter-wheat.

[3] R. L. Anderson, "Diversity and no-till: keys for pest management in the U.S. great plains," Weed Science, vol. 56, no. 1, pp. 141-145, 2008.

[4] H. P. Byker, N. Soltani, D. E. Robinson, F. J. Tardif, M. B. Lawton, and P. H. Sikkema, "Occurrence of glyphosate and cloransulam resistant Canada fleabane (Conyza canadensis L. Cronq.) in Ontario," Canadian Journal of Plant Science, vol. 93, no. 5, pp. 851-855, 2013.

[5] C. M. Budd, N. Soltani, D. E. Robinson, D. C. Hooker, R. T. Miller, and P. H. Sikkema, "Distribution of glyphosate and cloransulan-methyl resistant Canada fleabane (Conyza canadensis (L.) Cronq.) in Ontario," Canadian Journal of Plant Science, vol. 98, no. 2, pp. 492-497, 2018.

[6] M. L. Flessner, J. A. Dille, P. H. Sikkema, I. C. Burke, W. J. Everman, and M. VanGessel, Perspectives on Wheat Yield Losses Due to Weeds in North America, Weed Science Society of America, Lawrence, KS, USA, 2020, http://wssa.net/ wp-content/uploads/Wheat-yield-loss-POSTER.pdf.

[7] G. R. Kruger, V. M. Davis, S. C. Weller, and W. G. Johnson, "Response and survival of rosette-stage horseweed (Conyza canadensis) after exposure to 2,4-D," Weed Science, vol. 56, no. 5, pp. 748-752, 2008.

[8] J. Quinn, N. Soltani, J. Ashigh, D. C. Hooker, D. E. Robinson, and P. H. Sikkema, "Halauxifen-methyl controls glyphosateresistant horseweed (Conyza canadensis) but not giant ragweed (Ambrosia trifida) in winter wheat," Weed Technology, vol. 35, pp. 1-6, 2020.

[9] Statistical Analysis Systems (SAS), The SAS System for Windows, Release 9.4, Statistical Analysis Systems Institute, Cary, NC, USA, 2014.

[10] N. Soltani, C. Shropshire, and P. H. Sikkema, "Responses of winter wheat (Triticum aestivum L.) to autumn applied postemergence herbicides," Crop Protection, vol. 25, no. 4, pp. 346-349, 2006.

[11] M. A. Robinson, J. Letarte, M. J. Cowbrough, P. H. Sikkema, and F. J. Tardif, "Winter wheat (Triticum aestivum L.) response to herbicides as affected by application timing and temperature," Canadian Journal of Plant Science, vol. 95, no. 2, pp. 335-338, 2015.

[12] K. J. Mahoney, K. E. McNaughton, and P. H. Sikkema, "Control of glyphosate-resistant horseweed in winter wheat 
with pyrasulfotole premixed with bromoxynil," Weed Technology, vol. 30, no. 1, pp. 291-296, 2016.

[13] S. S. Reddy, P. W. Stahlman, P. W. Geier, and D. E. Peterson, "Broadleaf weed control and crop safety with premixed pyrasulfotole and bromoxynil in winter wheat," American Journal of Plant Sciences, vol. 03, no. 11, pp. 1613-1618, 2012.

[14] S. W. Bingham, E. G. Rucker, and R. L. Shaver, "Broadleaf weed species' response to turfgrass herbicides," in Proceedings of the Southern Weed Science Society 39th Annual Meeting, p. 110, Southern Weed Science Society, Champaign, IL, USA, 1986.

[15] G. R. Kruger, V. M. Davis, S. C. Weller, and W. G. Johnson, "Control of horseweed (Conyza canadensis) with growth regulator herbicides," Weed Technology, vol. 24, no. 4, pp. 425-429, 2010.

[16] G. R. Kruger, V. M. Davis, S. C. Weller, and W. G. Johnson, "Growth and seed production of horseweed (Conyza canadensis) populations after exposure to postemergence 2,4-D," Weed Science, vol. 58, no. 4, pp. 413-419, 2010.

[17] V. Kumar, P. Jha, and A. J. Jhala, "Confirmation of glyphosate-resistant horseweed (Conyza canadensis) in montana cereal production and response to POST herbicides," Weed Technology, vol. 31, no. 6, pp. 799-810, 2017.

[18] M. Zimmer, B. G. Young, and W. G. Johnson, "Weed control with halauxifen-methyl applied alone and in mixtures with 2,4-D, dicamba, and glyphosate," Weed Technology, vol. 32, no. 5, pp. 597-602, 2018.

[19] M. Zimmer, B. G. Young, and W. G. Johnson, "Herbicide programs utilizing halauxifen-methyl for glyphosate-resistant horseweed (Conyza canadensis) control in soybean," Weed Technology, vol. 32, no. 6, pp. 659-664, 2018.

[20] C. L. McCauley, W. G. Johnson, and B. G. Young, "Efficacy of halauxifen-methyl on glyphosate-resistant horseweed (Erigeron canadensis)," Weed Science, vol. 66, no. 6, pp. 758-763, 2018. 